\title{
Clinical Significance of Retinoic Acid Receptor Beta Promoter Methylation in Prostate Cancer: A Meta-Analysis
}

\author{
MengMeng Dou ${ }^{\mathrm{a}} \quad$ XueLiang Zhou ${ }^{\mathrm{b}} \quad$ ZhiRui Fan $^{\mathrm{b}} \quad$ XianFei Ding $^{\mathrm{c}} \quad$ LiFeng Li $^{\mathrm{b}}$ \\ ShuLing Wang ${ }^{d}$ Wenhua Xue ${ }^{e}$ Hui Wang ${ }^{a}$ Zhenhe Suo ${ }^{b, f, g}$ XiaoMing Deng ${ }^{a}$ \\ aDepartment of Integrated Traditional and Western Medicine, The First Affiliated Hospital of \\ Zhengzhou University, Zhengzhou, ${ }^{b}$ Department of Oncology, The First Affiliated Hospital of \\ Zhengzhou University, Zhengzhou, 'Department of General ICU, The First Affiliated Hospital of \\ Zhengzhou University, Zhengzhou, ${ }^{d}$ Department of Pathology, The Basic Medical Institute of \\ Zhengzhou University, Zhengzhou, eDepartment of Pharmacy, The First Affiliated Hospital of \\ Zhengzhou University, Zhengzhou, China; 'Department of Pathology, The Norwegian Radium Hospital, \\ Oslo University Hospital, University of Oslo, Montebello, Oslo, ${ }^{9}$ Department of Pathology, Institute for \\ Clinical Medicine, Faculty of Medicine, University of Oslo, Oslo, Norway
}

\section{Key Words}

Retinoic acid receptor beta $•$ Methylation $•$ Prostate cancer $・$ Risk $•$ Meta-analysis

\begin{abstract}
Background/Aims: Retinoic acid receptor beta (RAR beta) is a retinoic acid receptor gene that has been shown to play key roles during multiple cancer processes, including cell proliferation, apoptosis, migration and invasion. Numerous studies have found that methylation of the RAR beta promoter contributed to the occurrence and development of malignant tumors. However, the connection between RAR beta promoter methylation and prostate cancer (PCa) remains unknown. This meta-analysis evaluated the clinical significance of RAR beta promoter methylation in PCa. Materials and Methods: We searched all published records relevant to RAR beta and PCa in a series of databases, including PubMed, Embase, Cochrane Library, ISI Web of Science and CNKI. The rates of RAR beta promoter methylation in the $\mathrm{PCa}$ and control groups (including benign prostatic hyperplasia and normal prostate tissues) were summarized. In addition, we evaluated the source region of available samples and the methods used to detect methylation. To compare the incidence and variation in RAR beta promoter methylation in $\mathrm{PCa}$ and non-PCa tissues, the odds ratio $(O R)$ and $95 \%$ confidence interval $(\mathrm{Cl})$ were calculated accordingly. All the data were analyzed with the statistical software STATA 12.0. Results: Based on the inclusion and exclusion criteria, 15 articles assessing 1,339 samples were further analyzed. These data showed that the RAR beta promoter methylation rates in PCa tissues were significantly higher than the rates in the non-PCa group (OR=21.65, 95\% Cl: 9.27-50.57). Subgroup analysis according to the source region of samples showed that heterogeneity in Asia was small $\left(I^{2}=0.0 \%, P=0.430\right)$. Additional subgroup analysis based on the method used to detect RAR beta promoter methylation showed that the heterogeneity M. Dou and X. Zhou contributed equally to this work.
\end{abstract}

XiaoMing Deng and Zhenhe Suo
Dpt. of Integrated Traditional and Western Medicine, The First Affiliated Hospital of

Zhengzhou University, Zhengzhou, Henan Province, (China)

E-Mail hndengxiaoming@126.com, zhenhes@medisin.uio.no

\section{KARGER}




\section{Cellular Physiology Cell Physiol Biochem 2018;45:2497-2505

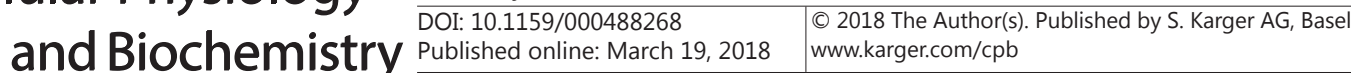 \\ Dou et al.: Retinoic Acid Receptor Beta Promoter Methylation in Prostate Cancer}

detected by MSP (methylation-specific PCR) was relatively small $\left(R^{2}=11.3 \%, P=0.343\right)$. Conclusion: Although studies reported different rates for RAR beta promoter methylation in PCa tissues, the total analysis demonstrated that RAR beta promoter methylation may be correlated with PCa carcinogenesis and that the RAR beta gene is particularly susceptible. Additional studies with sufficient data are essential to further evaluate the clinical features and prognostic utility of RAR beta promoter methylation in PCa.

\section{Introduction}

Prostate cancer (PCa) predominantly affects male patients and is associated with considerable morbidity and mortality. According to data from 2016, there were 161, 360 new PCa cases in the United States, and 26, 730 patients died from PCa [1]. The molecular mechanisms involved in malignant PCa progression include multiple sequential genetic and epigenetic events [2]. Prostate-specific antigen (PSA) and/or rectal digital examination are the main methods for diagnosing PCa [3]. However, PSA is specific to prostate tissue, not PCa [4], and two large trials have suggested that the net benefit of PSA measurement is marginal at best, whereas the harms are substantial [5]. Controversy also remains regarding whether current screening methods can be applied to the early diagnosis and treatment of PCa [6].

Agrowing body of evidence [7-12] has shown that epigenetic alterations show promise for future translational applications in molecular pathology detection and prognostic evaluation. DNA methylation is an epigenetic event with an important role regulating gene expression. In particular, hypermethylation of the promoter region often leads to transcriptional repression and causes transcriptional silencing in malignant tumors, including PCa [13]. Promoters have critical functions in PCa progression and can differentiate PCa from benign alterations [14]. Retinoic acid, the metabolite of vitamin A [15] , inhibits tumor growth by interacting with its receptor, especially retinoic acid receptor beta (RAR beta) $[16,17]$. RAR beta has two different subtypes that express different RNA transcripts [18], with the RAR beta-2 isoform predominantly expressed in most human cells. The methylation rate of the RAR beta-2 isoform promoter in patients with initial PCa and HIPC (hormone-independent $\mathrm{PCa}$ ) was reported to be $79 \%$ and $90 \%$, respectively, although normal prostate and benign prostatic hyperplasia (BPH) tissues were not analyzed [2].

Many records have reported that aberrant RAR beta promoter methylation occurs in hepatocellular carcinoma (HCC) [19], breast cancer [20] and non-small-cell lung carcinoma (NSCLC) [21]. Nevertheless, relevant analyses examining the association between RAR beta promoter methylation and PCa are lacking. Thus, we summarized all relevant published articles and performed further analysis. Changes in RAR beta promoter methylation occurred in the early stages of PCa [22] and have been analyzed using a PCR-based detection technique, which shows high sensitivity and could be ideal for biomarker detection. Therefore, our meta-analysis may provide additional information identifying potential biomarkers for early PCa diagnosis.

\section{Materials and Methods}

Retrieval strategy

We searched available studies up to March 2017 in the PubMed, Embase, Cochrane Library, ISI Web of Science and CNKI databases using the corresponding combination of subject words and free words: "prostate cancer," "prostatic neoplasms," [Mesh] "retinoic acid receptor beta" and "methylation". In addition, the references of the included articles and reviews were also retrieved.

Selection criteria of eligible studies

The following inclusion criteria were applied: 1. Published original literature examining the relationship between RAR beta promoter methylation and PCa. 2. The purpose of the study and the statistical methods 


\section{Cellular Physiology Cell Physiol Biochem 2018;45:2497-2505 \\ and Biochemistry Published online: March 19, 2018 \begin{tabular}{l|l} 
DOI: 10.1159/000488268 2018 The Author(s). Published by S. Karger AG, Basel \\
www.karger.com/cpb
\end{tabular} \\ Dou et al.: Retinoic Acid Receptor Beta Promoter Methylation in Prostate Cancer}

were similar, and the data were complete. 3. Methylation of the RAR beta promoter was detected using PCRbased methods. 4. All the patients met the diagnostic criteria for $\mathrm{PCa}$, and all the studies were independent case-control studies. 5 . An odds ratio $(O R)$ with a $95 \%$ confidential interval $(C I)$ was reported.

\section{Exclusion criteria of alternative studies}

The following exclusion criteria were applied: 1 . The study was an animal study. 2 . The study was a cell line study. 3. The study was a review or meta-analysis. 4. No data on the relationship between RAR beta promoter methylation and PCa were provided. 5. There were defects in the study design or the data were incomplete.

\section{Literature screening}

According to the information extraction protocol, two researchers searched the literature independently. Then, the title and abstracts of each available study were evaluated based on the inclusion/ exclusion criteria. If the title and abstracts were not controversial and could be evaluated, we chose to read the full text. Throughout the search process, a third researcher had the right to make the ultimate decision in cases of disagreement.

\section{Data extraction}

The data extraction was performed independently by 2 researchers, and any disagreement was resolved through panel discussions. The extracted information included the following: first author, publication year, source region, study type, the RAR beta promoter methylation rate in the PCa group and the control group (normal prostate tissue or $\mathrm{BPH}$ ), the methods of methylation detection, and the OR with $95 \% \mathrm{CI}$.

\section{Statistical analyses}

All the data were analyzed using the statistical software STATA 12.0. The OR was expressed with the 95\% CI. If the OR was more than 1 and the $95 \%$ CI did not overlap, it was concluded that RAR beta promoter methylation increased PCa risk. If the $O R$ was less than 1, it was concluded that RAR beta promoter methylation decreased PCa risk. The test of heterogeneity was performed with a $\chi^{2}$ test and an $I^{2}$ test. If there was no statistical heterogeneity between the studies $\left(P=0.10\right.$ and $\left.I^{2}<50 \%\right)$, a fixed effects model was applied to the meta-analysis. Otherwise, a random effects model was used. In addition, subgroup analyses were stratified according to the patient source region and the method used to detect methylation to explore the differences and potential sources of heterogeneity. In the presence of heterogeneity, a sensitivity analysis was performed by removing the included studies one by one to evaluate whether a specific omission affected the overall outcome. Funnel plots were used to evaluate publication bias if more than 9 records were included. A P value less than 0.05 was considered statistically significant.

\section{Results}

The study inclusion procedure and study characteristics

Based on the retrieval strategy, 42 articles were included after the initial screening. According to further investigation, we found that 1 record was an editorial [23] and another was a meta-analysis [24]. After screening the full text, it was discovered that 7 articles focused on cell lines, 11 articles lacked complete data, and 7 articles were not case-control studies, and these were excluded from this study. Finally, 15 records, including 1,339 samples, were deemed eligible [2, 2538]. The publication year ranged from 2001 to 2014. A flow diagram of the included and

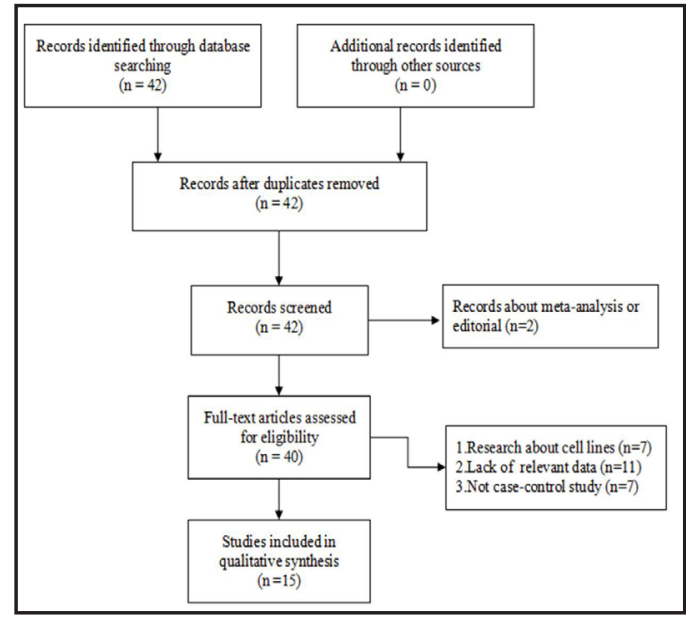

Fig. 1. Flow diagram of the included and excluded studies in this meta-analysis. 
Table 1. Characteristics of the studies included in the meta-analysis. MSP: methylation-specific PCR; Q-MSP: quantitative methylation-specific PCR; NMSP: nested methylation-specific PCR;

\begin{tabular}{|c|c|c|c|c|c|c|c|}
\hline Study & Study design & Region & Specimen type & Methods (techniques) & Control type & $\begin{array}{c}\text { Cases } \\
\text { Positive /Negative }\end{array}$ & $\begin{array}{c}\text { Controls } \\
\text { Positive /Negative }\end{array}$ \\
\hline Nakayama, T. et al, $2001[32]$ & Case-control & Asia & Tissue & Q-MSP & Normal prostate & $20 / 4$ & $0 / 10$ \\
\hline Maruyama, R. et al, $2002[31]$ & Case-control & North America & Tissue & MSP & Non-prostate cancer & $54 / 47$ & $1 / 31$ \\
\hline Woodson, K. et al, 2003[36] & Case-control & North America & Tissue & Q-MSP & BPH & $5 / 3$ & $0 / 7$ \\
\hline Yamanaka, M. et al, $2003[37]$ & Case-control & Asia & Tissue & MSP & Non-cancerous lesion & $85 / 24$ & $5 / 25$ \\
\hline Zhang, J. et al, 2003[2] & Case-control & North America & Tissue & MSP & Normal tissue & $42 / 8$ & $3 / 5$ \\
\hline Singal, R. et al, $2004[33]$ & Case-control & North America & Tissue & MSP & BPH & $32 / 49$ & $0 / 42$ \\
\hline Jeronimo, C. et al, 2004[30] & Case-control & Europe & Tissue & Q-MSP & BPH & $115 / 3$ & $7 / 23$ \\
\hline Tokumaru, Y. et al, 2004[35] & Case-control & Asia & Tissue & Q-MSP & Normal prostate & $54 / 7$ & $0 / 11$ \\
\hline Hanson, J. A. et al, 2006[29] & Case-control & Asia & Tissue & Q-MSP & Normal prostate & $5 / 0$ & $4 / 1$ \\
\hline Cho, N. Y. et al, 2006[26] & Case-control & Asia & Tissue & MSP & BPH & $123 / 56$ & $1 / 29$ \\
\hline Clark, J. P. et al, 2008[27] & Case-control & North America & Tissue & Q-MSP & BPH & NA & $\mathrm{NA}$ \\
\hline Zon, G. et al, 2009[38] & Case-control & North America & Tissue & MSP & BPH & $39 / 4$ & $0 / 22$ \\
\hline Ameri, A. et al, 2011[25] & Case-control & Asia & Tissue & MSP & BPH & $22 / 20$ & $0 / 21$ \\
\hline Tang, D. et al, 2013 [34] & Case-control & North America & Tissue & NMSP & BPH & $33 / 21$ & $16 / 38$ \\
\hline Daniunaite, K. et al, 2014 [28] & Case-control & Europe & Tissue & Q-MSP & BPH & $97 / 52$ & $3 / 14$ \\
\hline
\end{tabular}

Table 2. The Newcastle-Ottawa Scale (NOS) for assessing the quality of case-control studies

\begin{tabular}{|c|c|c|c|c|c|c|c|c|c|}
\hline Studies & & Selection & & & Comparability & & & Exposure & $\begin{array}{l}\text { Total } \\
\text { score }\end{array}$ \\
\hline Author and year & $\begin{array}{l}\text { Is the case definition } \\
\text { adequate? }\end{array}$ & $\begin{array}{l}\text { Representativeness of } \\
\text { the cases }\end{array}$ & $\begin{array}{c}\text { Selection of } \\
\text { controls }\end{array}$ & $\begin{array}{c}\text { Definition of } \\
\text { controls }\end{array}$ & $\begin{array}{l}\text { Studies controlling the most } \\
\text { important factors }\end{array}$ & $\begin{array}{l}\text { Studies controlling the } \\
\text { other main factors }\end{array}$ & $\begin{array}{l}\text { Ascertainment of } \\
\text { exposure }\end{array}$ & $\begin{array}{ccc}\begin{array}{c}\text { Same method of ascertaimment } \\
\text { for cases and controls }\end{array} & \begin{array}{c}\text { Non- } \\
\text { response rate }\end{array}\end{array}$ & \\
\hline $\begin{array}{l}\text { Nakayama, T. etal, } \\
20001[32]\end{array}$ & $\cdot$ & • & & • & + & • & • & $\cdot$ & 7 \\
\hline $\begin{array}{l}\text { Maruyama, R. et al, } \\
2002[31]\end{array}$ & * & * & & * & * & * & * & * & 7 \\
\hline $\begin{array}{l}\text { Woodson, K. et al, } \\
2003[36]\end{array}$ & * & * & * & * & * & . & * & * & 8 \\
\hline $\begin{array}{l}\text { Yamanaka, M. et al, } \\
2003[37]\end{array}$ & * & * & * & * & * & & * & * & 7 \\
\hline $\begin{array}{l}\text { Zhang, J. et al, } \\
\text { 2003[2] }\end{array}$ & * & * & . & * & * & . & * & * & 8 \\
\hline $\begin{array}{l}\text { Singal, R.et al, } \\
2004[33]\end{array}$ & * & * & & * & * & * & * & * & 7 \\
\hline $\begin{array}{l}\text { Jeronimo, c. et al, } \\
2004[30]\end{array}$ & * & * & & * & * & . & * & . & 7 \\
\hline $\begin{array}{l}\text { Tokifumaru, Y. et al, } \\
\text { To0435] }\end{array}$ & * & . & & * & . & * & * & . & 7 \\
\hline 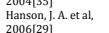 & * & * & & * & . & * & * & . & 7 \\
\hline $\begin{array}{l}\text { Cho, N. Y. Yet al, } \\
2006[26]\end{array}$ & * & * & & . & . & . & * & . & 7 \\
\hline $\begin{array}{l}\text { Clark, I. . et al, } \\
2008[27]\end{array}$ & * & * & & ${ }^{*}$ & . & * & $*$ & . & 7 \\
\hline $\begin{array}{l}\text { Zon, Ge et al, } \\
2009[38]\end{array}$ & * & . & . & . & . & . & * & * & 8 \\
\hline $\begin{array}{l}\text { Ameri. A e tal, } \\
201 \mid[25]\end{array}$ & * & . & * & * & . & * & * & * & 8 \\
\hline $\begin{array}{l}\text { Tann D. et al, } \\
\text { 2013[34] }\end{array}$ & . & * & . & . & * & . & * & * & 8 \\
\hline $\begin{array}{l}\text { Daniunaite, K. etal, } \\
2014[28]\end{array}$ & * & . & & * & . & * & . & . & 7 \\
\hline
\end{tabular}

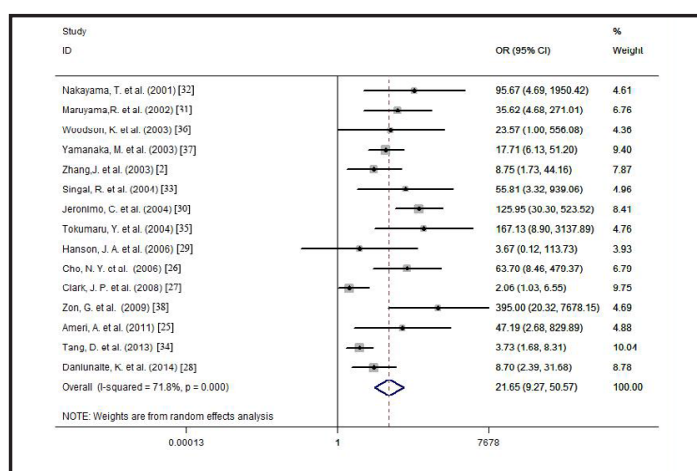

Fig. 2. The association between RAR beta promoter methylation and PCa risk using forest plots. OR: Odds ratio; CI: Confidence interval.

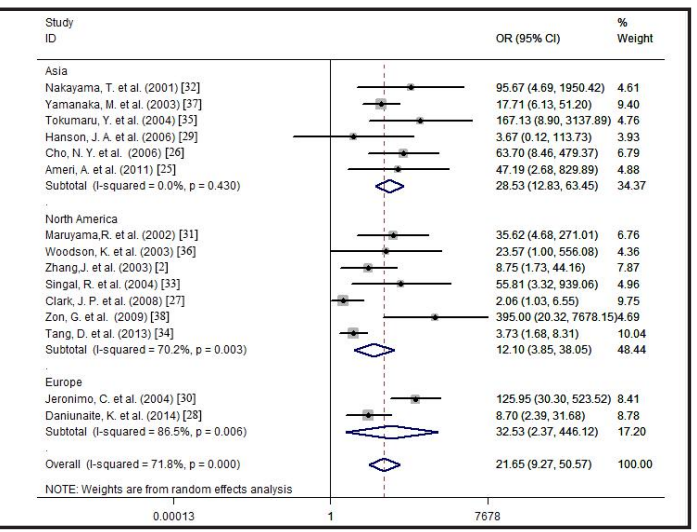

Fig. 3. Subgroup analysis according to patient source region using forest plots.

excluded studies and the characteristics of the studies included in the meta-analysis are shown in Fig. 1 and Table 1.

The quality of case-control studies as assessed by the Newcastle-Ottawa Scale (NOS)

We used the Newcastle-Ottawa Scale (NOS) to assess the quality of the 15 included records, as recommended by the Cochrane Non-Randomized Studies Methods Working Group [39]. The table consists of 3 blocks, including selection, comparability and assessment of the outcome, for a total of 9 entries. The NOS uses a semi-quantitative star system to evaluate study quality; 9 stars corresponds to "perfect", and more than 5 stars indicates "high-quality". All the details are shown in Table 2. 


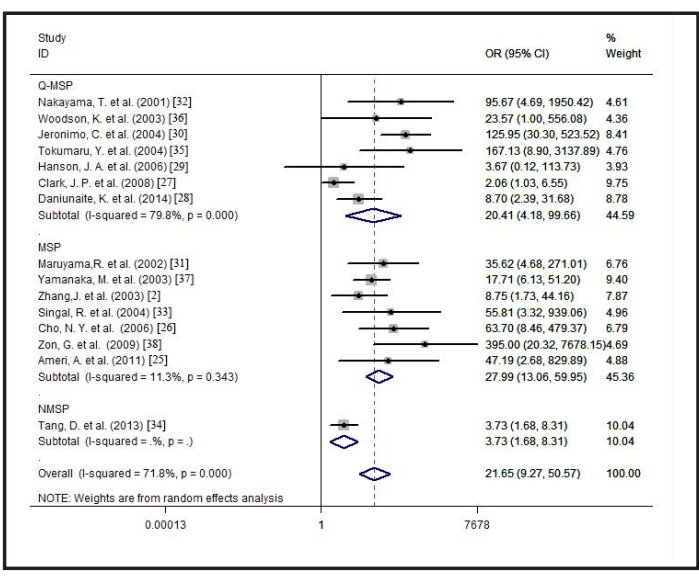

Fig. 4. Subgroup analysis according to methylation detection method using forest plots.

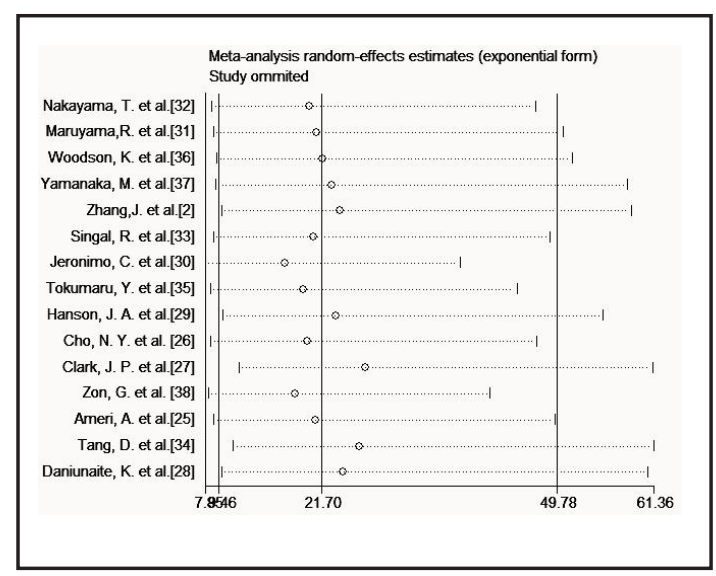

Fig. 5. Sensitivity analysis for the association between RAR beta promoter methylation and PCa risk.
RAR beta promoter methylation differences in $P C a$ and non-PCa tissues

As shown in Fig. 2, 15 studies reported the relationship between RAR beta promoter methylation and PCa risk. Because significant heterogeneity between studies was identified $\left(I^{2}=71.80 \%, P=0.000\right)$, a random effects model was used for the meta-analysis. The ultimate outcome suggested that the methylation rate of the RAR beta promoter in PCa tissues was significantly higher than that of the nonPCa group (OR=21.65, 95\% CI: 9.27-50.57). In addition, RAR beta promoter methylation increased PCa risk by 21.65 -fold. To explore the source of the significant heterogeneity, a subgroup analysis of patient source region and methylation detection method was performed. As shown in Fig. 3, the heterogeneity of the metaanalysis in Asia was small $\left(I^{2}=0.0 \%, P=0.430\right)$. Further subgroup analysis according to RAR beta promoter methylation detection method showed that the heterogeneity from MSP (methylationspecific PCR) was relatively small $\left(I^{2}=11.3 \%\right.$, $P=0.343$ ) (Fig. 4). The subgroup analysis results indicated that the heterogeneity of the studies might be caused by regional differences in disease incidence or differences in the methylation detection methods.

\section{The analysis of sensitivity and publication} bias

In addition, due to the presence of heterogeneity, a sensitivity analysis was performed by removing the included studies one by one to assess whether a specific omission affected the overall outcome. As shown in Fig. 5, the results were not altered significantly after excluding any of the 15 articles, demonstrating the stability of this meta-analysis. Moreover, a funnel 


\section{Cellular Physiology Cell Physiol Biochem 2018;45:2497-2505 \\ and Biochemistry Published online: March 19, $2018 \quad$\begin{tabular}{l|l} 
DOI: 10.1159/000488268 2018 The Author(s). Published by S. Karger AG, Basel \\
www.karger.com/cpb
\end{tabular} \\ Dou et al.: Retinoic Acid Receptor Beta Promoter Methylation in Prostate Cancer}

plot was used to test the potential publication bias of the included studies. As shown in Fig. 6 , the scatter of the points in the funnel plot was asymmetric, suggesting publication bias. Thus, the filled funnel plot method was applied to adjust the bias and calculate the number of unpublished studies that may have led to asymmetry (Fig. 7). The results showed that the adjusted $O R(O R=7.97,95 \% C I: 3.33-19.10, P=0.000)$ was similar to that of the previous summary. Therefore, the sensitivity analysis and publication bias tests demonstrated the stability of the ultimate conclusion of this meta-analysis.

\section{Discussion}

PCa is one of the most common malignant tumors and a major public health problem, and its incidence is likely to increase as the population ages [40]. Because the specific molecular mechanisms of PCa remain unclear and current PCa screening methods cannot precisely differentiate malignant cancers from begin prostatic hyperplasia [41], it is necessary to find novel biomarkers for better screening and fast, accurate PCa diagnosis. Researchers [42-44] have increasingly realized that epigenetic alterations are involved in the early stages of PCa development, even in precancerous lesions.

Methylation of the RAR beta promoter is an epigenetic biomarker that has been extensively studied in PCa. This alteration has been detected in many studies $[25,28,34$, 38], although some have reported controversial results [27, 29, 36]. Cho, NY et al [26]. examined the RAR beta promoter methylation level in 179 cases of prostate adenocarcinoma and 30 cases of BPH using MSP. These authors found that the gene methylation frequencies in PCa were significantly higher than those in BPH $(123 / 179,1 / 30)$, indicating that RAR beta promoter methylation was cancer-related (OR=63.70, 95\% CI: 8.46-479.37). However, Hanson JA et al [29]. did not observe obvious differences in RAR beta promoter methylation between tumor epithelium and histologically normal-appearing epithelium (in all five patients and in four of five samples, respectively). Thus, the relationship between RAR beta promoter methylation and PCa warrants further research.

Our meta-analysis showed that RAR beta promoter methylation levels were significantly higher in PCa patients than in non-PCa patients $(O R=21.65,95 \% C I$ : 9.27-50.57, $P=0.000)$, suggesting a potential role for this type of methylation in the malignant progression of PCa. We also performed subgroup analysis to explore the potential impact of the source region and methylation detection method on the association between RAR beta promoter methylation and PCa. The outcomes showed the following regional RAR beta promoter methylation rates: Europe (OR=32.53, 95\% CI: 2.37-446.12, $P=0.006)$, Asia $(O R=28.53,95 \%$ CI: 12.83 63.45, $P=0.430)$, and North America (OR=12.10, 95\% CI: 3.85-38.05, $P=0.003)$. Of note, the correlation in Europe was apparently higher than that in Asia and North America, and this difference may be due to genetic background, environment, and sample size. Because the RAR beta promoter methylation levels were detected using different methods, we also performed a subgroup analysis according to methylation detection method to identify potential sources of heterogeneity and differences between studies. The results showed that the heterogeneity detected by MSP was relatively small $\left(I^{2}=11.3 \%, P=0.343\right)$, indicating that some of the heterogeneity between studies may be due to differences in the methylation detection methods used. The sensitivity analysis and publication bias tests demonstrated the stability of the ultimate conclusion in this meta-analysis.

In brief, the RAR beta gene is a major PCa susceptibility gene. A study by Cho et al. from 2009 identified more than 50 genes inactivated by promoter CpG island hypermethylation in PCa, and the most relevant other than RAR beta include GSTP1, RASSF1, and $p 16$ [24]. Regarding the relationship between RAR beta and other genes, Moison C et al [45]. found that hypermethylation of the RAR beta promoter was positively correlated with H3K27me3 enrichment. Nevertheless, Zhang J et al [2]. demonstrated that the promoter methylation levels of TIG1 (tazarotene-induced gene 1, also known as retinoid acid receptor-responsive 1 gene) and RAR beta were positively correlated ( $r=0.35 ; P=0.017)$. However, the specific 


\section{Cellular Physiology Cell Physiol Biochem 2018;45:2497-2505 \begin{tabular}{l|l} 
and Biochemistry Published online: March 19, 2018 & $\begin{array}{l}\text { C } 2018 \text { The Author(s). Published by S. Karger AG, Basel } \\
\text { www.karger.com/cpb }\end{array}$
\end{tabular} \\ Dou et al.: Retinoic Acid Receptor Beta Promoter Methylation in Prostate Cancer}

mechanism of this interaction remains unclear, and whether the same CpGs were analyzed in the selected articles is worth future studies. Moreover, Roupre M et al [46]. observed that men with advanced PCa and biochemical recurrence experienced a significant increase in RAR beta promoter hypermethylation between the initial diagnosis (first blood sample) and the time to progression (second blood sample), with the highest methylation frequencies observed in PCa patients compared with those in age-matched controls. In this study, all the data were from clinical research tissue samples. Thus, data concerning RAR beta promoter methylation in cell lines are insufficient, especially in stem cell lines that would likely support cancer progression. Additional research is required to explore the specific mechanisms concerning RAR beta promoter methylation in cell lines and the interaction between RAR beta and other relevant genes.

\section{Acknowledgements}

We would like to thank our anonymous reviewers and professional editors for their excellent suggestions and comments which helped to improve our work. And we thank all authors for their hard work.

\section{Disclosure Statement}

The authors disclose no potential conflicts of interest.

\section{References}

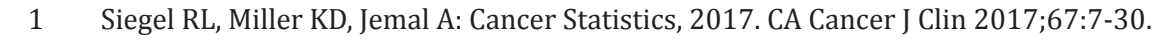

-2 Zhang J, Liu L, Pfeifer GP: Methylation of the retinoid response gene TIG1 in prostate cancer correlates with methylation of the retinoic acid receptor beta gene. Oncogene 2004;23:2241-2249.

$>3$ Cook ED, Nelson AC: Prostate cancer screening. Curr Oncol Rep 2011;13:57-62.

4 Daniunaite K, Berezniakovas A, Jankevicius F, Laurinavicius A, Lazutka JR, Jarmalaite S: Frequent methylation of RASSF1 and RARB in urine sediments from patients with early stage prostate cancer. Medicina (Kaunas) 2011;47:147-153.

5 Pinsky PF, Prorok PC, Kramer BS: Prostate Cancer Screening - A Perspective on the Current State of the Evidence. N Engl J Med 2017;376:1285-1289.

6 Fleshner K, Carlsson SV, Roobol MJ: The effect of the USPSTF PSA screening recommendation on prostate cancer incidence patterns in the USA. Nat Rev Urol 2017;14:26-37.

7 Valdes-Mora F, Clark SJ: Prostate cancer epigenetic biomarkers: next-generation technologies. Oncogene 2015;34:1609-1618.

-8 Quantitative comparison of DNA methylation assays for biomarker development and clinical applications. Nat Biotechnol 2016;34:726-737.

9 Assie G, Letouze E, Fassnacht M, Jouinot A, Luscap W, Barreau O, Omeiri H, Rodriguez S, Perlemoine K, Rene-Corail F, Elarouci N, Sbiera S, Kroiss M, Allolio B, Waldmann J, Quinkler M, Mannelli M, Mantero F, Papathomas T, De Krijger R, Tabarin A, Kerlan V, Baudin E, Tissier F, Dousset B, Groussin L, Amar L, Clauser E, Bertagna X, Ragazzon B: Integrated genomic characterization of adrenocortical carcinoma. 2014;46:607612.

10 Heyn H, Esteller M: DNA methylation profiling in the clinic: applications and challenges. Nat Rev Genet 2012;13:679-692.

11 Qu X, Othus M, Davison J, Wu Y, Yan L, Meshinchi S, Ostronoff F, Estey EH, Radich JP, Erba HP, Appelbaum FR, Fang M: Prognostic methylation markers for overall survival in cytogenetically normal patients with acute myeloid leukemia treated on SWOG trials. Cancer 2017;123:2472-2481. 


\section{Cellular Physiology Cell Physiol Biochem 2018;45:2497-2505 \begin{tabular}{l|l} 
Dnd Biochemistry Published online: March 19, 2018 & $\begin{array}{l}\text { (c) } 2018 \text { The Author(s). Published by S. Karger AG, Basel } \\
\text { www.karger.com/cpb }\end{array}$
\end{tabular}

12 Xu Y, Gao AM, Ji LJ, Li X, Zhong LL, Li HL, Zheng DH: All-Trans Retinoic Acid Attenuates Hypoxia-Induced Injury in NRK52E Cells via Inhibiting NF-x03BA;B/VEGF and TGF-beta2/VEGF Pathway. Cell Physiol Biochem 2016;38:229-236.

-13 Lodygin D, Epanchintsev A, Menssen A, Diebold J, Hermeking H: Functional epigenomics identifies genes frequently silenced in prostate cancer. Cancer Res 2005;65:4218-4227.

14 Moritz R, Ellinger J, Nuhn P, Haese A, Muller SC, Graefen M, Schlomm T, Bastian PJ: DNA hypermethylation as a predictor of PSA recurrence in patients with low- and intermediate-grade prostate cancer. Anticancer Res 2013;33:5249-5254.

15 Yin S, Bleul T, Zhu Y, Isayev 0, Werner J, Bazhin AV: MiRNAs are Unlikely to be Involved in Retinoid Receptor Gene Regulation in Pancreatic Cancer Cells. Cell Physiol Biochem 2017;44:644-656.

16 Li Y, Gao Y, Cui T, Yang T, Liu L, Li T, Chen J: Retinoic Acid Facilitates Toll-Like Receptor 4 Expression to Improve Intestinal Barrier Function through Retinoic Acid Receptor Beta. Cell Physiol Biochem 2017;42:1390-1406.

17 Abed M, Alzoubi K, Lang F, Al Mamun Bhuayn A: Stimulation of Phospholipid Scrambling of the Erythrocyte Membrane by 9-Cis-Retinoic Acid. Cell Physiol Biochem 2017;41:543-554.

18 Vilhais-Neto GC, Maruhashi M, Smith KT, Vasseur-Cognet M, Peterson AS, Workman JL, Pourquie O: Rere controls retinoic acid signalling and somite bilateral symmetry. Nature 2010;463:953-957.

19 Zhang C, Li J, Huang T, Duan S, Dai D, Jiang D, Sui X, Li D, Chen Y, Ding F, Huang C, Chen G, Wang K: Metaanalysis of DNA methylation biomarkers in hepatocellular carcinoma. Oncotarget 2016;7:81255-81267.

20 Gyorffy B, Bottai G, Fleischer T, Munkacsy G, Budczies J, Paladini L, Borresen-Dale AL, Kristensen VN, Santarpia L: Aberrant DNA methylation impacts gene expression and prognosis in breast cancer subtypes. Int J Cancer 2016;138:87-97.

-21 Huang T, Chen X, Hong Q Deng Z, Ma H, Xin Y, Fang Y, Ye H, Wang R, Zhang C, Ye M, Duan S: Meta-analyses of gene methylation and smoking behavior in non-small cell lung cancer patients. Sci Rep 2015;5:8897.

-22 Rataj-Baniowska M, Niewiadomska-Cimicka A, Paschaki M: Retinoic Acid Receptor beta Controls Development of Striatonigral Projection Neurons through FGF-Dependent and Meis1-Dependent Mechanisms. 2015;35:14467-14475.

-23 Lotan R, Lotan Y: Retinoic acid receptor beta2 hypermethylation: implications for prostate cancer detection, prevention, and therapy. Clin Cancer Res 2004;10:3935-3936.

24 Jiang D, Shen Y, Dai D, Xu Y, Xu C, Zhu H, Huang T, Duan S: Meta-analyses of methylation markers for prostate cancer. Tumour Biol 2014;35:10449-10455.

25 Ameri A, Alidoosti A, Hosseini SY, Parvin M, Emranpour MH, Taslimi F, Salehi E, Fadavip P: Prognostic Value of Promoter Hypermethylation of Retinoic Acid Receptor Beta (RARB) and CDKN2 (p16/MTS1) in Prostate Cancer. Chin J Cancer Res 2011;23:306-311.

26 Cho NY, Kim BH, Choi M, Yoo EJ, Moon KC, Cho YM, Kim D, Kang GH: Hypermethylation of CpG island loci and hypomethylation of LINE-1 and Alu repeats in prostate adenocarcinoma and their relationship to clinicopathological features. J Pathol 2007;211:269-277.

-27 Clark JP, Munson KW, Gu JW, Lamparska-Kupsik K, Chan KG, Yoshida JS, Kawachi MH, Crocitto LE, Wilson TG, Feng Z, Smith SS: Performance of a single assay for both type III and type VI TMPRSS2:ERG fusions in noninvasive prediction of prostate biopsy outcome. Clin Chem 2008;54:2007-2017.

28 Daniunaite K, Jarmalaite S, Kalinauskaite N, Petroska D, Laurinavicius A, Lazutka JR, Jankevicius F: Prognostic value of RASSF1 promoter methylation in prostate cancer. J Urol 2014;192:1849-1855.

-29 Hanson JA, Gillespie JW, Grover A, Tangrea MA, Chuaqui RF, Emmert-Buck MR, Tangrea JA, Libutti SK, Linehan WM, Woodson KG: Gene promoter methylation in prostate tumor-associated stromal cells. J Natl Cancer Inst 2006;98:255-261.

-30 Jeronimo C, Henrique R, Hoque MO, Ribeiro FR, Oliveira J, Fonseca D, Teixeira MR, Lopes C, Sidransky D: Quantitative RARbeta2 hypermethylation: a promising prostate cancer marker. Clin Cancer Res 2004;10:4010-4014.

-31 Maruyama R, Toyooka S, Toyooka KO, Virmani AK, Zochbauer-Muller S, Farinas AJ, Minna JD, McConnell J, Frenkel EP, Gazdar AF: Aberrant promoter methylation profile of prostate cancers and its relationship to clinicopathological features. Clin Cancer Res 2002;8:514-519.

32 Nakayama T, Watanabe M, Yamanaka M, Hirokawa Y, Suzuki H, Ito H, Yatani R, Shiraishi T: The role of epigenetic modifications in retinoic acid receptor beta2 gene expression in human prostate cancers. Lab Invest 2001;81:1049-1057. 


\section{Cellular Physiology Cell Physiol Biochem 2018;45:2497-2505

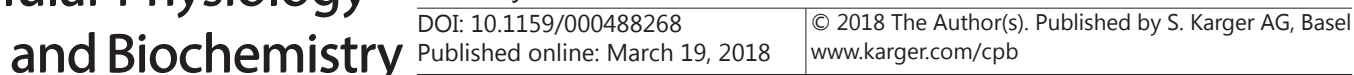 \\ Dou et al:: Retinoic Acid Receptor Beta Promoter Methylation in Prostate Cancer}

-33 Singal R, Ferdinand L, Reis IM, Schlesselman JJ: Methylation of multiple genes in prostate cancer and the relationship with clinicopathological features of disease. Oncol Rep 2004;12:631-637.

34 Tang D, Kryvenko ON, Mitrache N, Do KC, Jankowski M, Chitale DA, Trudeau S, Rundle A, Belinsky SA, Rybicki BA: Methylation of the RARB gene increases prostate cancer risk in black Americans. J Urol 2013;190:317-324.

-35 Tokumaru Y, Harden SV, Sun DI, Yamashita K, Epstein JI, Sidransky D: Optimal use of a panel of methylation markers with GSTP1 hypermethylation in the diagnosis of prostate adenocarcinoma. Clin Cancer Res 2004;10:5518-5522.

-36 Woodson K, Hanson J, Tangrea J: A survey of gene-specific methylation in human prostate cancer among black and white men. Cancer Lett 2004;205:181-188.

-37 Yamanaka M, Watanabe M, Yamada Y, Takagi A, Murata T, Takahashi H, Suzuki H, Ito H, Tsukino H, Katoh T, Sugimura Y, Shiraishi T: Altered methylation of multiple genes in carcinogenesis of the prostate. Int J Cancer 2003;106:382-387.

38 Zon G, Barker MA, Kaur P, Groshen S, Jones LW, Imam SA, Boyd VL: Formamide as a denaturant for bisulfite conversion of genomic DNA: Bisulfite sequencing of the GSTPi and RARbeta2 genes of 43 formalin-fixed paraffin-embedded prostate cancer specimens. Anal Biochem 2009;392:117-125.

39 Stang A: Critical evaluation of the Newcastle-Ottawa scale for the assessment of the quality of nonrandomized studies in meta-analyses. Eur J Epidemiol 2010;25:603-605.

40 Gronberg H, Adolfsson J, Aly M, Nordstrom T, Wiklund P, Brandberg Y, Thompson J, Wiklund F, Lindberg J, Clements M, Egevad L, Eklund M: Prostate cancer screening in men aged 50-69 years (STHLM3): a prospective population-based diagnostic study. Lancet Oncol 2015;16:1667-1676.

41 Vasiljevic N, Wu K, Brentnall AR, Kim DC, Thorat MA, Kudahetti SC, Mao X, Xue L, Yu Y, Shaw GL, Beltran L, Lu YJ, Berney DM, Cuzick J, Lorincz AT: Absolute quantitation of DNA methylation of 28 candidate genes in prostate cancer using pyrosequencing. Dis Markers 2011;30:151-161.

-42 Haldrup C, Mundbjerg K, Vestergaard EM, Lamy P, Wild P, Schulz WA, Arsov C, Visakorpi T, Borre M, Hoyer S, Orntoft TF, Sorensen KD: DNA methylation signatures for prediction of biochemical recurrence after radical prostatectomy of clinically localized prostate cancer. J Clin Oncol 2013;31:3250-3258.

43 Pixberg CF, Raba K, Muller F, Behrens B, Honisch E, Niederacher D, Neubauer H, Fehm T, Goering W, Schulz WA, Flohr P, Boysen G, Lambros M, De Bono JS, Knoefel WT, Sproll C, Stoecklein NH, Neves RPL: Analysis of DNA methylation in single circulating tumor cells. Oncogene 2017;36:3223-3231.

44 Truong M, Yang B, Livermore A, Wagner J, Weeratunga P, Huang W, Dhir R, Nelson J, Lin DW, Jarrard DF: Using the epigenetic field defect to detect prostate cancer in biopsy negative patients. J Urol 2013;189:2335-2341.

45 Moison C, Assemat F, Daunay A, Tost J, Guieysse-Peugeot AL, Arimondo PB: Synergistic chromatin repression of the tumor suppressor gene RARB in human prostate cancers. Epigenetics 2014;9:477-482.

46 Roupret M, Hupertan V, Catto JW, Yates DR, Rehman I, Proctor LM, Phillips J, Meuth M, Cussenot O, Hamdy FC: Promoter hypermethylation in circulating blood cells identifies prostate cancer progression. Int J Cancer 2008;122:952-956. 